\title{
TENDENCJE CENTRALIZACYJNE WE WSPÓLNYM EUROPEJSKIM SYSTEMIE AZYLOWYM
}

\section{Uwagi wprowadzające}

Pojęcia centralizacji i decentralizacji jako systemów ustrojowych administracji publicznej nie odnoszą się wprost do relacji zachodzących między Unią Europejską a państwami członkowskimi, a ściślej - między organami administrującymi na tych dwóch poziomach w europejskiej przestrzeni prawnej. Relacjami ustrojowymi między Unią a jej członkami rządzą zasada odrębności (autonomii) instytucjonalnej państw członkowskich (art. 4 ust. 2 TUE), a w aspekcie funkcjonalnego podziału i realizacji zadań i kompetencji - zasady kompetencji przyznanych, pomocniczości, proporcjonalności oraz lojalnej współpracy (art. 4 ust. 1 i 3 oraz art. 5 TUE) ${ }^{1}$. Mylne byłoby jednak przekonanie, że pojęcia te nie pełnią funkcji opisowej, wyjaśniającej czy wartościującej również w odniesieniu do administracji unijnej sensu largo, tj. do administracji składającej się z instytucji, organów i jednostek organizacyjnych Unii oraz organów państw członkowskich. Należy jednak od razu zastrzec, że pojęcia te nie odpowiadają

* Barbara Kowalczyk - doktor nauk prawnych, Instytut Nauk Administracyjnych, Uniwersytet Wrocławski.

1 Zob. R. Grzeszczak, Władza wykonawcza w systemie Unii Europejskiej, Warszawa 2011, s. 59 i n. 
modelowym ujęciom właściwym dla badania stosunków ustrojowych na podstawie krajowego prawa ustrojowego. Tradycyjną aparaturę pojęciową należy odpowiednio zmodyfikować, aby odpowiadała realiom prawnym europejskiej przestrzeni prawnej (administracyjnej).

Całość zintegrowanej administracji europejskiej opisuje się jako w istocie zdecentralizowaną (ang. de-central) i zorientowaną subsydiarnie (ang. subsidiarity-oriented) strukturę organizacyjną ${ }^{2}$. Unia Europejska nie posiada własnej administracji w poszczególnych państwach i korzysta głównie z krajowego aparatu administracyjnego. Organy państw członkowskich są funkcjonalnie traktowane jak organy Unii w procesie wykonywania prawa unijnego i w związku z tym dominuje model stosowania prawa określany jako zdecentralizowany. Oczekiwanym bądź wymaganym sposobem realizacji zadań i kompetencji jest współpraca administracyjna, koordynowana bądź wspierana przez odpowiednie instytucje, organy i jednostki organizacyjne $\mathrm{UE}^{3}$. Z uwagi na zasadę przyznania i zasadę subsydiarności pierwotnym i naturalnym stanem administracji UE sensu largo jest dekoncentracja i decentralizacja, zaś ruch kompetencji ma postać koncentracji i centralizacji.

Pojęcie decentralizacji pojawia się także w odniesieniu do europejskich agencji regulacyjnych, które określa się tym mianem zarówno w dokumentach politycznych ${ }^{4}$, jak i literaturze ${ }^{5}$. Agencje są uznawane za formę decentralizowania działań wykonawczych na poziomie Unii - z jednej strony - z powodu przejmowania kompetencji od Komisji, a z drugiej - z uwagi na strukturalną integrację krajowych organów

${ }^{2}$ H.C.H. Hofmann, European administration: nature and developments of a legal and political space [w:] Research handbook on EU administrative law, red. C. Harlow, G. della Cananea, P. Leino, Edward Elgar Publishing 2017, s. 41. Jest to jeden z wielu sposób charakteryzowania systemu administracyjnego UE.

3 Zob. art. 197 TFUE.

4 Wspólne oświadczenie Parlamentu Europejskiego, Rady UE i Komisji Europejskiej $w$ sprawie zdecentralizowanych agencji, https://europa.eu/european-union/sites/ europaeu/files/docs/body/joint_statement_and_common_approach_2012_pl.pdf (dostęp: 11.11 .2018 r.).

${ }^{5}$ Np. H.C.H. Hofmann, European..., s. 29. Obszernej na temat agencji europejskich zob. J. Supernat, Administracja Unii Europejskiej. Zagadnienia wybrane, Wrocław 2013, s. 96-116. 
administracji i włączenie ich w działalność agencji. Jako istotna część systemu instytucjonalnego UE, bez którego trudno już dzisiaj wyobrazić sobie funkcjonowanie administracji unijnej, znajdują się pomiędzy instytucjami UE a państwami członkowskimi. W ich ogólnej charakterystyce zwykle podkreśla się zalety takiego sposobu zorganizowania wykonywania prawa i polityki UE. Argumentami za tworzeniem agencji są m.in. polityczna neutralność technicznych i naukowych ocen, wzmocnienie wiarygodności i zaufania do unijnego procesu decyzyjnego (w swym początkowym okresie funkcjonowania agencje były postrzegane jako potencjalny substytut komitologii), budowa odpowiedniej infrastruktury administracyjnej na poziomie europejskim oraz umożliwienie, wzmocnienie i koordynowanie współpracy państw członkowskich, a tym samym też zdobywanie czy odbudowywanie społecznego zaufania w odniesieniu do skutecznego implementowania polityk unijnych ${ }^{6}$. Zauważa się też, że powoływanie agencji jest często odpowiedzią na kryzys ${ }^{7}$.

Agencje regulacyjne odgrywają kluczową rolę w procesie integracji i zapewnienia jednolitości stosowania unijnej polityki i prawa, zwłaszcza tam, gdzie pełna harmonizacja prawa nie jest możliwa czy pożądana. Są to podmioty umożliwiające w wyznaczonym obszarze koordynację oraz współpracę administracyjną zarówno na poziomie ponadnarodowym, jak i pomiędzy poszczególnymi państwami członkowskimi. Tym samym utrzymana jest w mocy zasada zdecentralizowanego stosowania prawa UE przy jednoczesnej możliwie jednolitej implementacji ${ }^{8}$. Relacje z państwami członkowskimi i ich organami są zbudowane ma modelu sieciowym. Agencje są rodzajem primus inter pares wśród krajowych organów, nie są wobec nich hierarchicznie zwierzchnie, chociaż w praktyce mają istotny głos i wpływ na uczestników ustanowionej sieci'.

${ }^{6}$ M. Everson, E. Vos, European Agencies: What about the Institutional Balance?, „Maastricht Faculty of Law Working Paper” 2014/4, s. 4.

7 I. Lipowicz, Wpływ Unii Europejskiej na strukturę administracji państw członkowskich [w:] Administracja pod wpływem prawa europejskiego, red. D. Dolnicki, J. Jagoda, Bydgoszcz-Katowice 2006, s. 139.

${ }^{8}$ M. Everson, E. Vos, European..., s. 3.

9 M. Everson, E. Vos, European..., s. 6. 
Często zadania i kompetencje agencji są znacznie silniejsze niż wspieranie państw członkowskich w implementacji polityk i prawa unijnego. Gromadzenie, wymiana i udostępnianie informacji, ułatwianie współpracy czy zarządzanie siecią są domeną większości, ale część $\mathrm{z}$ nich wyposażona jest także w kompetencje wykonawcze, decyzyjne, kontrolne i nadzorcze. Administracja UE wykorzystuje zhierarchizowane struktury w zależności od polityki, potrzeby reakcji na sytuację (często kryzysową) w danym obszarze, czy brak efektywności dotychczasowych środków harmonizujących. Władza tych wykonawczych subcentrów ulega sukcesywnemu wzmacnianiu, polegającemu na stopniowym przydawaniu im regulacyjnej i decyzyjnej władzy oraz wzmacnianiu pozycji agencji w koordynacji administracyjnych sieci. Stanowi to wyraźny kierunek rozwoju administracji UE, mianowicie konsolidacyjny czy też inaczej mówiąc - centralizacyjny ${ }^{10}$. Utworzenie takiej agencji oznacza dla państw nie tylko instytucjonalizację ich współpracy, ale jest też postrzegane właśnie w kategoriach centralizacji, gdyż następuje konkretyzacja kompetencji UE i niejednokrotnie przejmowanie zadań organów państw członkowskich ${ }^{11}$. Jak pisze I. Lipowicz, „scentralizowane stosowanie prawa wspólnotowego [...] było przez długie lata wyjątkiem [...] «kariera» agencji europejskich i możliwość wydawania już przez niektóre z nich aktów administracyjnych przynosi zasadniczą zmianę w tym pejzażu. Traktowana poważnie zasada subsydiarności była przez długie lata hamulcem scentralizowanego stosowania prawa wspólnotowego. Obecnie - w związku z rozwojem administracji sieciowej zasada ta ulega pewnej erozji, którą należy ocenić krytycznie"12. To dążenie do centralizacji nie może jednak dziwić, bo jak zauważa J. Boć - pisząc o administracji krajowej - rozrost tendencji centralistycznych

${ }^{10}$ Szerzej zjawisko wraz z jego ograniczeniami analizuje E. Chiti, In the Aftermath of the Crisis - The EU Administrative System between Impediments and Momentum, „Cambridge Yearbook of European Legal Studies” 17 (2015), s. 313-318, 322.

${ }^{11}$ M. Dyl, A. Paczkowska-Tomaszewska, R. Stankiewicz, M. Wierzbowski, Zarys systemu podmiotów administrujących w Unii Europejskiej [w:] System Prawa Administracyjnego, t. 6, Podmioty administrujące, red. R. Hauser, A. Wróbel, Z. Niewiadomski, Warszawa 2011, s. 569.

${ }^{12}$ I. Lipowicz, Europeizacja i modernizacja. Administracyjno-prawne aspekty zmian polskiej administracji publicznej [w:] Europeizacja administracji publicznej. Zbiór studiów, red. I. Lipowicz, Warszawa 2008, s. 19. 
i ich instytucjonalizacja są stałe ${ }^{13}$. W odniesieniu do administracji UE można także znaleźć dowody na prawdziwość tego twierdzenia. W świetle preambuły i art. $1 \mathrm{zd}$. 2 TUE wyraźnie powstaje napięcie między „coraz ściślejszym związkiem” (ang. the ever closer union) między narodami Europy a podejmowaniem decyzji ,jak najbliżej obywateli”. Sposób zorganizowania wykonywania władzy publicznej w europejskiej przestrzeni prawnej wpisuje się w jedną z podstawowych debat na temat prawa europejskiego, która dotyczy granic integracji i utrzymania odpowiedniego stopnia autonomii instytucji krajowych ${ }^{14}$.

\section{Europejski Urząd Wsparcia w dziedzinie Azylu}

Wspólny Europejski System Azylowy (dalej jako: WESA) jest jednym z elementów przestrzeni wolności, bezpieczeństwa i sprawiedliwości, jaką ma być UE dla swoich obywateli; powiązane są z tym środki odnoszące się do kontroli granic zewnętrznych, azylu, imigracji (art. 3 ust. 2 TUE). WESA jako idea stworzenia wspólnej przestrzeni prawnej w dziedzinie ochrony cudzoziemców pojawił się we wnioskach Rady Europejskiej z posiedzenia w Tampere (1999 r.), a pierwotne podstawy prawne znalazł w art. 63 ust. 1 i 2 TWE w wersji Traktatu z Amsterdamu. Obecnie podstawę WESA stanowi przepis art. 78 TFUE, który jest rozwinięciem art. 67 TFUE, mówiącego, że „Unia stanowi przestrzeń wolności, bezpieczeństwa i sprawiedliwości w poszanowaniu praw podstawowych oraz różnych systemów i tradycji prawnych Państw Członkowskich”. Brzmienie tego przepisu powinno determinować głębokość ingerencji unijnej regulacji w prawodawstwo państw

13 J. Boć [w:] Prawo administracyjne, red. J. Boć, Wrocław 2007, s. 230. W innym miejscu, w swobodniejszej wypowiedzi, pisze: „Ta centralizacja ma dużą siłę, być może jest to układ boski, być może jest to wzór nie do ominięcia. Wszystko na świecie jest scentralizowane, stado wilków też jest scentralizowane. Komórka, Układ Słoneczny. Może jest to nie do pokonania. Może centralizacja jest urządzeniem bardziej boskim niż decentralizacja. Tego na razie nie wiemy" - zob. J. Boć [w:] Zadania i obowiązki gmin w postępowaniu z odpadami komunalnymi. Materiały z konferencji na Uniwersytecie Wrocławskim, 16-17 października 2012 r., red. M. Górski, K. Nowacki, Wrocław 2013, s. 117.

14 A. von Bogdandy, The Idea of European Public Law Today [w:] The Max Planck Handbooks in European Public Law, t. 1, The Administrative State, red. A. von Bogdandy, P.M. Huber, S. Cassese, Oxford University Press 2017, s. 16. 
członkowskich. Wprawdzie podejmowane działania mają zmierzać do prowadzenia „wspólnej polityki” azylowej, opartej na solidarności i podziale odpowiedzialności między państwami członkowskimi ${ }^{15}$ oraz sprawiedliwej wobec obywateli państw trzecich, trzeba jednak pamiętać, że sprawy z zakresu przestrzeni wolności, bezpieczeństwa i sprawiedliwości należą do kompetencji dzielonych z państwami członkowskimi (art. 4 ust. 2 lit. j TFUE) i realizowane muszą być zgodnie z zasadą subsydiarności i proporcjonalności. Nie bez znaczenia jest także historyczny aspekt wspólnotowej polityki imigracyjnej i azylowej, która została zainicjowana w związku z wprowadzeniem rynku wewnętrznego i jest niejako ubocznym produktem "projektu 1992”"

Pierwszy etap tworzenia WESA zakończył się ostatecznie pod koniec 2005 r. Wynik kilkuletniego, niełatwego procesu legislacyjnego nie spełnił pokładanych w WESA oczekiwań. Treść regulacji aktów prawa wtórnego pozostawiała państwom szeroki zakres swobody, prowadzący w istocie do „renacjonalizacji” spraw azylowych. W konsekwencji nie zniwelowano niepożądanych różnic w prawie i praktyce państw członkowskich. Już w 2004 r. zapoczątkowano kolejny etap procesu tworzenia WESA ${ }^{17}$, dla którego podstawę prawną stanowił art. 78 TFUE. Ten przepis to także podstawa proponowanych zmian lub podjęcia zupełnie nowych regulacji składających się na WESA, których konieczność została wywołana tzw. kryzysem migracyjnym w 2015 r. Ambicją Komisji i stanem docelowym jest ujednolicenie prawa i przyjęcie w przyszłości wspólnego kodeksu azylowego, wzajemne uznawanie decyzji o azylu oraz ustanowienia jednego procesu decyzyjnego ${ }^{18}$. Zmianom prawa materialnego i procesowego mają towarzyszyć zmiany w funkcjonowaniu wymiaru organizacyjnego WESA.

15 Zob. art. 80 TFUE.

${ }_{16}$ M. Gondek, Polityka azylowa Unii Europejskiej po Traktacie Amsterdamskim [w:] Szkice z prawa Unii Europejskiej, t. 2, Prawo materialne, red. E. Piontek, A. Zawidzka, Kraków 2003, s. 119.

17 W przyjętym w listopadzie 2004 r. Programie Haskim: Wzmacnianie Wolności, Bezpieczeństwa i Sprawiedliwości w Unii Europejskiej (Dz.Urz. UE C 53, s. 1) wyznaczono cele drugiego etapu tworzenia WESA na lata 2006-2010.

18 Zob. Komunikat Komisji do Parlamentu Europejskiego, Rady, Europejskiego Komitetu Ekonomiczno-Społecznego i Komitetu Regionów Europejski Program w zakresie migracji z 13.05.2015 r., COM(2015) 240 final, s. 21. 
Dotychczas WESA jest administrowany w sposób najbardziej typowy dla administracji Unii Europejskiej sensu largo. Ciężar odpowiedzialności za realizację zadań wyznaczonych w prawie UE spoczywa na administracji państwa członkowskiego, korzystającej z przysługujących jej kompetencji i form służących ich wykonywaniu. Ponadto przewidziane są różnego rodzaju formy kooperacji i współpracy administracyjnej, odpowiadające ogólnym tendencjom rozwojowym administracji unijnej. Jedną z nich jest Europejski Urząd Wsparcia w dziedzinie Azylu (dalej jako: Urząd lub EASO). Za utworzeniem agencji w 2010 r. ${ }^{19}$ przemawiały nie tylko wspomniane wyżej korzyści płynące z tworzenia takich organów UE. Utworzenie Urzędu było także odpowiedzią na kryzys WESA i brak postępów w implementacji przepisów unijnych ${ }^{20}$. „Integracja przez prawo” musiała być wzmocniona alternatywnym modelem harmonizacji, tj. środkami instytucjonalnymi.

Z zamierzenia Urząd jest „europejskim centrum eksperckim w dziedzinie azylu”, mającym za zadanie zapewnić ściślejszą współpracę polityczną i praktyczną między państwami członkowskimi UE. Analizując rozporządzenie ustanawiające Urząd, można wskazać trzy podstawowe grupy zagadnień objętych kompetencją agencji ${ }^{21}$, które mieszczą się w zakresie stałego, specjalnego lub kryzysowego wsparcia państw. Pierwsza to wspieranie praktycznej współpracy państw członkowskich w sprawach azylu: dokonywanie analiz, ustalanie „najlepszych praktyk”, organizowanie i koordynowanie wymiany informacji, istotne zwłaszcza w odniesieniu do krajów pochodzenia azy-

19 Rozporządzenie Parlamentu Europejskiego i Rady (UE) nr 439/2010 z 19.05.2010 r. w sprawie utworzenia Europejskiego Urzędu Wsparcia w dziedzinie Azylu (Dz.Urz. UE L 132 s. 11) - dalej jako: rozporządzenie nr 439/2010. Urząd ma siedzibę w Valletcie.

${ }^{20}$ Utworzenie europejskiej agencji wspierającej różne formy współpracy między państwami członkowskimi dotyczącej WESA (ułatwianie wymiany informacji, analiz i doświadczeń) zakładał Program Haski. Opcja stworzenia agencji regulacyjnej w dziedzinie azylu była rozważana przez Komisję w jej komunikacie dotyczącym agencji regulacyjnych z marca 2008 r. $\operatorname{COM}(2008)$ 135). W komunikacie przewidziano moratorium na tworzenie nowych agencji regulacyjnych, co jednak nie dotyczyło agencji w dziedzinie azylu.

${ }^{21}$ Wskazuje je zasadniczo art. 1 rozporządzenia, a szczegółowo zadania Urzędu określa rozdział 2 rozporządzenia nr 439/2010. 
lantów, szkolenia, wspieranie relokacji osób korzystających z ochrony w krajach UE. Druga grupa zadań jest szczególnie wymagająca i budzi niejednokrotnie pytania o zakres mandatu EASO. Bez wątpienia jest także „laboratorium” proponowanych zmian, do pewnego stopnia sankcjonujących obecną praktykę. Chodzi tu o zapewnienie wsparcia operacyjnego (lub koordynacja takiego wsparcia) dla krajów UE, których systemy azylowe znajdują się pod szczególną presją z powodu swojego położenia geograficznego, sytuacji demograficznej lub nagłego przybycia dużej liczby obywateli państw trzecich wymagających międzynarodowej ochrony; w tym przypadku również chodzi o wymianę informacji, a ponadto tworzenie i koordynację działania zespołów wsparcia w dziedzinie azylu ${ }^{22}$ oraz działania mające pomóc państwom członkowskim w usprawnieniu wstępnej analizy wniosków i udostępnieniu odpowiedniej infrastruktury do przyjmowania osób (zakwaterowanie, środki transportu, pomoc medyczna). Wymiernym efektem tego rodzaju działalności jest funkcjonowanie punktów Hotspot w Grecji i we Włoszech, zorganizowanych we współpracy $z$ agencjami Frontex i Europol oraz państwami członkowskimi, a także otwarcie biur agencji na Cyprze, Kos i Lesbos. Ostatnia grupa obejmuje usprawnienie procesu wdrażania WESA zarówno w jego wewnętrznym, jak i zewnętrznym wymiarze, w szczególności przez koordynację wymiany między zainteresowanymi stronami informacji odnoszących się do wdrażania instrumentów prawnych z zakresu azylu, gromadzenie i udostępnianie informacji dotyczących prawodawstwa krajowego i praktyki rozpatrywania wniosków o azyl ${ }^{23}$.

Urząd sporządza roczne sprawozdanie na temat sytuacji w dziedzinie azylu w Unii, przyjmuje dokumenty techniczne dotyczące wdraża-

${ }^{22} \mathrm{Na}$ ich potrzeby Urząd tworzy tzw. rezerwę interwencyjną, składającą się z ekspertów o różnym profilu i tłumaczy; każde państwo członkowskie tworzy tzw. rezerwę krajową i w razie wnioskowania o wsparcie wyznacza krajowy punkt kontaktowy odpowiedzialny za komunikację z Urzędem we wszystkich sprawach dotyczących zespołów wsparcia w dziedzinie azylu, a rolę punktu kontaktowego na poziomie Unii pełni jeden (lub kilku) ekspert Urzędu wyznaczony przez dyrektora.

${ }^{23}$ Więcej szczegółowych informacji o działalności EASO w poszczególnych latach można znaleźć w rocznych raportach przygotowanych przez EASO na podstawie art. 29 ust. 1 lit. c rozporządzenia nr 439/2010, zob. https://www.easo.europa.eu/sites/default/ files/publications/EASO-Annual-General-Report-2017.pdf (dostęp: 9.12.2018 r.). 
nia instrumentów Unii w dziedzinie azylu, takie jak wytyczne i podręczniki postępowania, które jednakże nie mogą stanowić instrukcji dla państw członkowskich „w zakresie przyjmowania lub odrzucania wniosków o przyznanie ochrony międzynarodowej"24.

W niedługi czas po rozpoczęciu działalności Urzędu efekty jego pracy stały się także fundamentem mechanizmu wczesnego ostrzegania, gotowości i zarządzania kryzysowego, ustanowionego rozporządzeniem Dublin III $^{25}$. Informacje zebrane przez EASO służą do uruchomienia tego mechanizmu. Jeżeli Komisja na tej podstawie ustali, że stosowanie rozporządzenia, którego przedmiotem jest podział odpowiedzialności za rozpatrywanie wniosków azylowych (tzw. system dubliński), może zostać narażone na szwank z uwagi na znaczne ryzyko szczególnego obciążenia systemu azylowego państwa członkowskiego lub $\mathrm{z}$ uwagi na problemy $\mathrm{z}$ funkcjonowaniem systemu azylowego państwa członkowskiego, to kieruje do takiego państwa członkowskiego zalecenia, w których zachęca do opracowania planu działań zapobiegawczych. Kolejnym krokiem może być zwrócenie się do państwa członkowskiego o opracowanie planu działania w zakresie zarządzania kryzysowego i, w razie potrzeby, o wprowadzanie zmian do tego planu. W czasie całego procesu wczesnego ostrzegania, gotowości i zarządzania kryzysowego Rada monitoruje sytuację i może się zwrócić o dalsze informacje, a także wydać wytyczne polityczne, zwłaszcza jeżeli chodzi o nagły charakter i powagę sytuacji, a zatem konieczność przygotowania przez państwo członkowskie albo planu działań zapobiegawczych, albo - w razie konieczności - planu działania w zakresie zarządzania kryzysowego. Parlament Europejski i Rada mogą w czasie całego procesu omawiać wszelkie środki solidarności i wydawać wytyczne w ich sprawie, jeśli uznają to za właściwe.

${ }^{24}$ Wszystkie publikacje dostępne są on-line, zob. https://www.easo.europa.eu/ information-analysis (dostęp: 11.11.2018 r.).

${ }^{25}$ Rozporządzenie Parlamentu Europejskiego i Rady (UE) nr 604/2013 z 26.06.2013 r. w sprawie ustanowienia kryteriów i mechanizmów ustalania państwa członkowskiego odpowiedzialnego za rozpatrzenie wniosku o udzielenie ochrony międzynarodowej złożonego w jednym z państw członkowskich przez obywatela państwa trzeciego lub bezpaństwowca (wersja przekształcona) (Dz.Urz. UE L 180, s. 31) - dalej jako: rozporządzenie Dublin III. 


\section{Agencja Unii Europejskiej ds. Azylu}

Należyte funkcjonowanie WESA budziło zastrzeżenia od czasu jego utworzenia. Kryzys migracyjny, który rozpoczął się w 2015 r., uwidocznił dobitnie słabości systemu, zwłaszcza gdy chodzi o jego fundament, tj. kryteria i mechanizm podziału odpowiedzialności za rozpatrywanie wniosków o ochronę międzynarodową. WESA charakteryzuje również - pomimo harmonizacji przepisów - zróżnicowane traktowanie osób ubiegających się o ochronę, zarówno jeśli chodzi o przesłanki udzielenia ochrony, jak i standardy proceduralne oraz warunki recepcji, co z kolei zachęca do wtórnych migracji. W reakcji na narastający kryzys humanitarny i kryzys bezpieczeństwa wywołany napływem do Europy największej liczby imigrantów od czasu zakończenia drugiej wojny światowej Komisja w maju 2015 r. opublikowała „Europejski Program w zakresie migracji”, a następnie w kwietniu 2016 r. przedstawiła założenia reformy WESA ${ }^{26}$. W maju i lipcu tego samego roku złożyła siedem projektów aktów prawnych w tym zakresie. Reforma o charakterze instytucjonalnym, polegająca na przekształceniu dotychczasowego EASO w Agencję Unii Europejskiej ds. Azylu (dalej jako: EUAA) ${ }^{27}$ znalazła się w pierwszym pakiecie propozycji, wraz z reformą systemu dublińskiego i zmianą funcjonowania systemu Eurodac. Proces legislacyjny jest w toku i postępuje w różnym tempie, ale trzeba podkreślić, że w przypadku wniosku dotyczącego EUAA osiągnięto w czerwcu 2017 r polityczne porozumienie $^{28}$. We wrześniu 2018 r. Komisja przedstawiła kolejny wniosek odnoszący się do Agencji, zmieniający niektóre z proponowanych

${ }^{26}$ Komunikat Komisji do Parlamentu Europejskiego i Rady: W kierunku reformy wspólnego europejskiego systemu azylowego i zwiększenia liczby legalnych sposobów migracji do Europy, COM(2016) 197. Komisja zaproponowała wprowadzenie zmian w pięciu priorytetowych obszarach: ustanowienie zrównoważonego i sprawiedliwego systemu ustalania państwa członkowskiego odpowiedzialnego za osoby ubiegające się o azyl; wzmocnienie systemu Eurodac, uzyskanie większej spójności unijnego systemu azylowego; zapobieganie wtórnym przepływom w UE oraz nadanie nowych uprawnień EASO.

27 Wniosek dotyczący rozporządzenia Parlamentu Europejskiego i Rady w sprawie Agencji Unii Europejskiej ds. Azylu i uchylającego rozporządzenie (UE) nr 439/2010, COM/2016/0271 final - 2016/0131 (COD) - dalej: projekt rozporządzenia EUAA.

${ }^{28}$ Dokument ST 128022017 INIT - 2016/0224 (COD). 
rozwiazań i wprowadzający nowe, jako rezultat tymczasowego porozumienia między Parlamentem Europejskim a Radą ${ }^{29}$. Celem jest wzmocnienie możliwości operacyjnych i technicznych agencji.

W czym wyrażają się wskazane w tytule opracowania tendencje centralistyczne w WESA? Z dotychczasowych ustaleń wynika, że już samo utworzenie EASO w 2010 r. było przejawem centralizacji, oczywiście w ujęciu zmodyfikowanym dla potrzeb europejskiej przestrzeni prawnej. Kolejny krok to istotne wzmocnienie agencji i przekształcenie jej w „agencję o pełnym zakresie funkcji” (ang. fully-fledged agency) ${ }^{30}$. Warto przy tym wspomnieć, że wiele zaproponowanych rozwiązań jest wzorowanych na wprowadzonej już reformie Europejskiej Agencji Straży Granicznej i Przybrzeżnej (Frontex) ${ }^{31}$. Najogólniej można powiedzieć, że Agencja Unii Europejskiej ds. Azylu dostaje nową funkcję realizacji polityki azylowej oraz wzmocnioną rolę operacyjną (art. 2 projektu rozporządzenia EUAA). W tym celu Agencja zostaje wyposażona w nowe instrumenty nadzoru, kontroli i koordynacji. Ma nie tylko wspierać państwa członkowskie w ich praktycznej współpracy, ale również „umacniać i dopełniać” ich systemy azylowe. Jak czytamy w motywie 6 projektu rozporządzenia: „Agencja powinna stać się ośrodkiem wiedzy fachowej, a jej podstawową rolą powinno być wzmocnienie praktycznej współpracy i wymiany informacji między państwami członkowskimi w kwestiach dotyczących azylu, propagowanie unijnych przepisów i norm operacyjnych w celu zapewnienia wysokiego stopnia jednolitości procedur azylowych, warunków przyjmowania oraz oceny potrzeb w zakresie ochrony w całej Unii, monitorowanie operacyjnego i technicznego stosowania unijnego prawa i norm do-

${ }^{29}$ Zmieniony wniosek dotyczący rozporządzenia Parlamentu Europejskiego i Rady w sprawie Agencji Unii Europejskiej ds. Azylu i uchylającego rozporządzenie (UE) nr 439/2010, COM(2018) 633 final - 2016/0131 (COD).

${ }^{30}$ Projekt rozporządzenia EUAA, s. 3.

${ }^{31}$ Rozporządzenie Parlamentu Europejskiego i Rady (UE) 2016/1624 z 14.09.2016 r. w sprawie Europejskiej Straży Granicznej i Przybrzeżnej oraz zmieniające rozporządzenie Parlamentu Europejskiego i Rady (UE) 2016/399 i uchylające rozporządzenie (WE) nr 863/2007 Parlamentu Europejskiego i Rady, rozporządzenie Rady (WE) nr 2007/2004 i decyzję Rady 2005/267/WE (Dz.Urz. UE L 251, s. 1 ze zm.) - dalej jako: rozporządzenie w sprawie Europejskiej Straży Granicznej i Przybrzeżnej / rozporządzenie 2016/1624. 
tyczących azylu, wspieranie systemu dublińskiego oraz zapewnienie państwom członkowskim wsparcia operacyjnego i technicznego w zakresie zarządzania systemami azylowymi i systemami przyjmowania, zwłaszcza państwom członkowskim zmagającym się z nieproporcjonalną presją wywieraną na ich systemy”. W tym celu Komisja proponuje szereg środków, m.in. nałożenie na Agencję i państwa obowiązku współpracy i wymiany informacji oraz przydanie Agencji uprawnienia do ustanawiania sieci (art. 3), tworzenie baz danych przez Agencję (art. 5), obowiązkowe szkolenia ekspertów krajowej administracji, sądów i trybunałów, krajowych służb odpowiedzialnych za kwestie azylu, w tym także opracowania wspólnego podstawowego programu szkoleń (art. 7), utworzenie sieci informacji o krajach pochodzenia azylantów oraz wydawanie wiążących wytycznych dotyczących sytuacji w państwach pochodzenia, mających na celu wyeliminowanie różnic w ocenie wniosków o ochronę międzynarodową (art. 10) oraz wspieranie Komisji w dokonywaniu regularnej weryfikacji wykazu bezpiecznych krajów pochodzenia (art. 11). Jednolitości orzecznictwa ma służyć także opracowywanie norm operacyjnych i wskazówek służących monitorowaniu zgodności z tymi normami; Agencja miałaby również opracowywać wytyczne dotyczące kwestii azylowych i umożliwić wymianę najlepszych praktyk przez państwa członkowskie (art. 12). Wzmocniona Agencja odgrywałaby także istotną rolę w procesie stosowania - przewidzianego w propozycji reformy systemu dublińskiego - mechanizmu korygującego i zarządzania nim (art. 6) ${ }^{32}$.

W rozdziale 5 projektu („Monitorowanie i ocena”) przewidziano dla Agencji nowe zadanie ${ }^{33}$, jakim jest monitorowanie wdrażania i ocena wszystkich aspektów WESA. Mechanizm obejmuje także monitorowanie przestrzegania przez państwa członkowskie norm operacyjnych,

\footnotetext{
32 Więcej na temat mechanizmu korygującego zob. projekt rozporządzenia Parlamentu Europejskiego i Rady w sprawie ustanowienia kryteriów i mechanizmów ustalania państwa członkowskiego odpowiedzialnego za rozpatrzenie wniosku o udzielenie ochrony międzynarodowej złożonego w jednym z państw członkowskich przez obywatela państwa trzeciego lub bezpaństwowca (wersja przekształcona), $\operatorname{COM(2016)~} 270$ final / 2-2016/0133 (COD).

${ }_{33}$ Można powiedzieć, że to bardziej zaawansowana odsłona wspomnianego wyżej mechanizmu wczesnego ostrzegania, gotowości i zarządzania kryzysowego stosowanego przez Komisję.
} 
wskaźników, wytycznych i najlepszych praktyk, a także weryfikowania realnych możliwości systemów azylowych i systemów przyjmowania, właczając w to ocenę tzw. zdolności administracyjnej i systemu sądowego, w zakresie efektywnego i prawidłowego rozpatrywania spraw azylowych i zarządzania nimi. Oznacza to monitorowanie sytuacji we wszystkich państwach członkowskich i określanie środków, jakie powinny zostać zastosowane przez państwa w celu zaradzenia występującym deficytom. Monitorowanie ma charakter systemowy, odbywać się ma na podstawie programu będącego częścią składową wieloletniego i rocznego planu prac Agencji. Każde państwo członkowskie ma zostać poddane monitorowaniu przynajmniej raz na pięć lat. Na potrzeby monitorowania Agencja ma utworzyć zespoły ekspertów, złożone z osób wyznaczonych przez Agencję i Komisję, które sporządzać będą sprawozdania. $\mathrm{Na}$ ich podstawie Zarząd Agencji przyjmuje zalecenia dla państwa członkowskiego i zwraca się do państwa o przedłożenie planu działania służącego wdrożeniu zaleceń. Realizacja planu działania trwa maksymalnie dziewięć miesięcy. Gdy po upływie tego terminu państwo członkowskie w dalszym ciągu nie zapewnia zgodności z zaleceniami, a waga uchybień zagraża funkcjonowaniu WESA, Komisja przyjmuje zalecenia i może, w razie potrzeby, wskazać środki, jakie Agencja podejmuje w celu udzielenia zainteresowanemu państwu członkowskiemu wsparcia. Jeżeli po terminie określonym w zaleceniach Komisji zainteresowane państwo członkowskie nadal nie zapewnia zgodności, Komisja może podjąć dalsze działania, wnioskując do Rady o wydanie decyzji zobowiązującej Agencję do podjęcia interwencji ${ }^{34}$.

${ }^{34} \mathrm{~W}$ projekcie rozporządzenia EUAA $\mathrm{w}$ brzmieniu pierwotnym kompetencja ta należała do Komisji, jednak w trakcie negocjacji międzyinstytucjonalnych brzmienie proponowanego przepisu uległo zmianie. Jak już wspomniano wyżej, propozycje dotyczące Agencji Unii Europejskiej ds. Azylu wzorowane były na projekcie rozporządzenia z 14.09.2016 r. w sprawie Europejskiej Straży Granicznej i Przybrzeżnej. Komisji nie udało się wówczas przeforsować wszystkich pomysłów, w tym najbardziej kontrowersyjnego, tzn. interwencji Agencji na podstawie decyzji Komisji bez zgody państwa członkowskiego. W uchwalonej wersji rozporządzenia 2016/1624 interwencja następuje na podstawie decyzji wykonawczej Rady, w oparciu o wniosek Komisji. Decyzja określa środki do wdrożenia przez Agencję mające na celu złagodzenie ryzyka zagrożenia funkcjonowaniu strefy Schengen i zobowiązuje dane państwo członkowskie do współpracy z Agencją przy wdrażaniu tych środków. Przed złożeniem wniosku Komisja zasięga opinii Agencji (art. 19 rozporządzenia 2016/1624). W preambule aktu czytamy, że: „Uprawnienia wykonawcze do przyjęcia takiej decyzji należy powierzyć Radzie 
W proponowanym rozporządzeniu (z uwględnieniem późniejszych zmian) znacząco rozszerzono zakres działań i modus operandi w odniesieniu do interwencji podejmowanych przez Agencję w celu udzielenia państwu członkowskiemu wsparcia operacyjnego i technicznego, zwłaszcza gdy systemy azylowe i systemy przyjmowania są poddane nieproporcjonalnej presji migracyjnej. W tym zakresie projekt rozporządzenia przewiduje trzy modele interwencji: na wniosek państwa członkowskiego, z inicjatywy Agencji za zgodą państwa członkowskiego (art. 16 ust. 1) oraz bez zgody państwa członkowskiego - na podstawie decyzji wykonawczej Rady (art. 22). Do środków pomocy operacyjnej i technicznej (lub zwiększonej pomocy) projekt zalicza (art. 16 i 16a) m.in. pomoc państwom członkowskim w identyfikacji i rejestracji obywateli państw trzecich; przeprowadzanie rejestracji wniosków o ochronę międzynarodową; pomoc przy rozpatrywaniu wniosków o ochronę międzynarodową albo też przeprowadzenie całej lub części procedury administracyjnej; przygotowywanie decyzji w sprawie wniosków o udzielenie ochrony międzynarodowej i przekazywanie ich właściwym organom krajowym; udzielanie wsparcia w rozpatrywaniu odwołań; pomoc w prowadzeniu procedury dublińskiej lub samodzielne przeprowadzenie tej procedury; doradztwo, wsparcie i koordynacja działań w zakresie tworzenia lub funkcjonowania ośrodków recepcyjnych; oddelegowywanie zespołów wsparcia ds. azylu. Oprócz zespołów wsparcia ds. azylu (art. 17) Agencja ma utworzyć także interwencyjną rezerwę ekspertów ds. azylu, liczącą nie mniej niż 500 osób (art. 18). O udziale każdego państwa w interwencyjnej rezerwie decydować ma zarząd Agencji.

\section{Zakończenie}

Podobnie jak utworzenie Europejskiej Agencji Straży Granicznej i Przybrzeżnej w 2016 r. było przełomowym wydarzeniem, w wyniku którego zarządzanie granicami zewnętrznymi UE przestało należeć wyłącznie do kompetencji organów krajowych i stało się wspólną odpowiedzial-

z uwagi na potencjalnie wrażliwy z politycznego punktu widzenia charakter środków, które wymagają decyzji, a które mogą wpływać na krajowe uprawnienia wykonawcze i uprawnienia w zakresie egzekwowania prawa" (motyw 28). 
nością państw członkowskich oraz Agencji ${ }^{35}$, tak utworzenie Agencji Unii Europejskiej ds. Azylu istotnie ograniczy samodzielność państw członkowskch (ich organów) w sprawach związanych z ochroną cudzoziemców na ich terytorium. Motto EASO support is our mission nabiera $\mathrm{w}$ tym kontekście nowego znaczenia. Jednocześnie nie są to rozwiązania wyłącznie na czas kryzysu, ale systemowe zmiany obrazujące tendencje rozwoju pluralistycznej administracji UE. Wskazane powyżej proponowane rozwiązania istotnie zmieniają model administrowania WESA, nadając mu kształt modelu scentralizowanego, z podziałem zadań i kompetencji na każdym szczeblu organizacyjnym oraz z możliwością władczego oddziaływania Agencji i instytucji UE na działalność organów krajowych. Nie wydaje się to przy tym rezultat konwergencji ostateczny, Komisja dąży bowiem w długookresowej perspektywie do wprowadzenia modelu klasycznej centralizacji. Do wspomnianego wcześniej celu ujednolicenia materialnego i procesowego prawa azylowego należy dołożyć rozważaną już od dawna możliwość przeniesienia odpowiedzialności za rozpatrywanie wniosków o udzielenie azylu ze szczebla krajowego na szczebel unijny, np. na agencję decyzyjną, która byłaby właściwa w pierwszej instancji, z krajowymi oddziałami w każdym państwie członkowskim, a także utworzenie na poziomie unijnym organu odwoławczego ${ }^{36}$. „W ten sposób powstałby jednolity i scentralizowany proces decyzyjny w pierwszej instancji i w postępowaniu odwoławczym, a tym samym zapewniona zostałaby pełna harmonizacja procedur, a także spójna ocena potrzeb w zakresie ochrony na szczeblu unijnym" ${ }^{37}$.

${ }_{35}$ Zob. art. 5 rozporządzenia 2016/1624.

${ }^{36}$ Komunikat Komisji do Parlamentu Europejskiego i Rady W kierunku reformy wspólnego europejskiego systemu azylowego i zwiększenia liczby legalnych sposobów migracji do Europy z 6.04.2016 r., $\operatorname{COM(2016)~} 197$ final, s. 9. Pierwsza próba wprowadzenia Agencji w proces decyzyjny w indywidualnych sprawach pojawiła się jako poprawka $54 \mathrm{w}$ projekcie sprawozdania w sprawie wniosku dotyczącego rozporządzenia Parlamentu Europejskiego i Rady w sprawie Agencji Unii Europejskiej ds. Azylu i uchylającego rozporządzenie (WE) nr 439/2010 (COM(2016) 0271 - C8-0174/2016 - 2016/0131(COD)), Komisja Wolności Obywatelskich, Sprawiedliwości i Spraw Wewnętrznych Parlamentu Europejskiego, gdzie dodano wspólne rozpatrywanie wniosków o ochronę międzynarodową, na wniosek zainteresowanego państwa członkowskiego.

37 Komunikat Komisji do Parlamentu Europejskiego i Rady w kierunku reformy wspólnego europejskiego systemu azylowego i zwiększenia liczby legalnych sposobów migracji do Europy, COM(2016) 197 final, s. 10. 


\section{Bibliografia:}

von Bogdandy A., The Idea of European Public Law Today [w:] The Max Planck Handbooks in European Public Law, t. 1, The Administrative State, red. A. von Bogdandy, P.M. Huber, S. Cassese, OUP 2017

Chiti E., In the Aftermath of the Crisis - The EU Administrative System between Impediments and Momentum, „Cambridge Yearbook of European Legal Studies" 2015/17

Dyl M., Paczkowska-Tomaszewska A., Stankiewicz R., Wierzbowski M., Zarys systemu podmiotów administrujących w Unii Europejskiej [w:] System Prawa Administracyjnego, t. 6, Podmioty administrujace, red. R. Hauser, A. Wróbel, Z. Niewiadomski, Warszawa 2011

Everson M., Vos E., European Agencies: What about the Institutional Balance?, „Maastricht Faculty of Law Working Paper” 2014/4

Gondek M., Polityka azylowa Unii Europejskiej po Traktacie Amsterdamskim [w:] Szkice z prawa Unii Europejskiej, t. 2, Prawo materialne, red. E. Piontek, A. Zawidzka, Kraków 2003

Grzeszczak R., Władza wykonawcza w systemie Unii Europejskiej, Warszawa 2011 Hofmann H.C.H., European administration: nature and developments of a legal and political space [w:] Research handbook on EU administrative law, red. C. Harlow, G. della Cananea, P. Leino, Edward Elgar Publishing 2017

Lipowicz I., Europeizacja i modernizacja. Administracyjno-prawne aspekty zmian polskiej administracji publicznej [w:] Europeizacja administracji publicznej. Zbiór studiów, red. I. Lipowicz, Warszawa 2008

Lipowicz I., Wpływ Unii Europejskiej na strukturę administracji państw członkowskich [w:] Administracja pod wplywem prawa europejskiego, red. D. Dolnicki, J. Jagoda, Bydgoszcz-Katowice 2006

Prawo administracyjne, red. J. Boć, Wrocław 2007

Supernat J., Administracja Unii Europejskiej. Zagadnienia wybrane, Wrocław 2013 Zadania i obowiazki gmin w postępowaniu z odpadami komunalnymi. Materialy z konferencji na Uniwersytecie Wrocławskim, 16-17 października 2012 r., red. M. Górski, K. Nowacki, Wrocław 2013 